\title{
COHESion in Polish-English translation AND ITS IMPLICATIONS FOR TRANSLATOR TRAINING
}

\author{
MARCIN LEWANDOWSKI \\ Adam Mickiewicz University, Poznań \\ marcinl@amu.edu.pl
}

\begin{abstract}
This paper focuses on the ways of maintaining cohesive links in the translation process in the Polish-English language pair. Of primary interest is how the thematic/rhematic structure of Polish sentences can be successfully rendered in English to produce cohesive, natural-sounding and communicative target texts with a proper information flow. These aspects have implications for translation teaching. It has been observed that, in view of the differences between Polish and English word order, university students at the start of their translator training experience two general problems as they attempt to translate longer stretches of text into English: (1) they produce cohesive passages, which contain errors in word order (due to syntactic interference from Polish) or (2) they produce grammatically correct sentences, which, however, form incohesive passages (i.e. ones in which the thematic/rhematic progression is not retained) with an inappropriate information structure. For this reason, students need to become acquainted with some practical solutions that help build cohesion in Polish-English translation. These include (1) shifts from active to passive, (2) other shifts in syntactic functions, (3) fronting, and (4) inventing sentence subjects out of broader context.
\end{abstract}

Keywords: translator training, contrastive grammar, Polish-English translation, cohesion in translation, word order

\section{Introduction}

The present contribution aims to show the relevance of cohesion in the translation process by explaining the nature of the problem from the perspective of English-Polish contrastive grammar and by demonstrating several ways of maintaining cohesion in Polish-English translation. The empirical material (extracts from texts designed for translations, students' translations and the actual published translations $)^{1}$ used to explicate the paper's major points has

\footnotetext{
${ }^{1}$ For the sake of easy reference, throughout the entire paper, the sources of the quoted extracts will be identified with abbreviations (the authors' initials and the language versions) followed by the page numbers where the extracts appear. The key to the abbreviations along with complete bibliographical information on the sources will be provided in a subsection of the References.
} 
been drawn from the author's translation classes attended by third-year undergraduate students enrolled in the Ethnolinguistics program at the Faculty of Modern Languages and Literatures, at Adam Mickiewicz University in Poznan, Poland. The classes, taught in the academic year 2019-20, were attended by a total of 30 students, seven of whom had had some previous translation experience (mostly as interns in translation agencies). The main research question addressed here is: what problems do translation trainees experience in the translation of academic texts in terms of maintaining cohesive links across sentences?

Within the theoretical background of the paper, cohesion will be discussed alongside the related notion of coherence. These two concepts, which are intertwined, yet sometimes confused and wrongly regarded as synonymous, have been variously defined, interpreted and investigated by major schools of linguistics, including the Prague linguistic circle (structuralists), generative linguistics, text linguistics, pragmatics and cognitive linguistics (for interesting insights into how these schools have approached cohesion and coherence, see Kaczmarek 2014). Given the subject matter of the paper, it is worthwhile providing a very brief overview of cohesion and coherence, primarily from a translation studies perspective.

According to a definition, cohesion "refers to the text-internal relationship of linguistic elements that are overtly linked via lexical and grammatical devices across sentence boundaries. The main types of cohesion generally stated in the literature are coreference, substitution/ellipsis, conjunction and lexical cohesion" (Menzel, Lapshinova-Koltunski and Kunz 2017: 1-2). The same authors perceive coherence to be a cognitive phenomenon, which involves "the logical flow of interrelated topics (or experiential domains) in a text, thus establishing a mental textual world" (Menzel, Lapshinova-Koltunski and Kunz 2017: 1). Under this distinction, coherence is viewed as a more abstract and elusive concept, as compared to cohesion, which is a linguistic manifestation of the textual relations between topics.

Similar views on these two notions are put forward by Kerremans (2017: 53), who argues that cohesion is an internal property of text (spoken and written) unlike coherence, which is assigned to the text by the reader or listener relying on their background knowledge as they attempt to make sense of the text. This approach echoes Blum-Kulka's (1986: 17) definition of coherence as "as a covert potential meaning relationship among parts of a text, made overt by the reader or listener through processes of interpretation". Cohesive relations differ from other semantic relations in that they occur across sentence boundaries (Halliday and Hassan 1976). In other words, cohesion through its lexicogrammatical markers (such as word order, pronouns, connectives and others (Halliday 1985: 38-9)) provides structural integrity and a sense of flow within the text whereas coherence ensures pragmatic and conceptual connectivity and a sense of focus (it allows the reader to focus their attention on a restricted number 
of semantically related concepts). However, it should be born in mind that cohesion and coherence are in fact strongly interconnected concepts. According to Tanskanen (2006: 7), who claims that coherence derives from the interaction (she actually uses the term 'dialogue') between the text and its recipients, "[a]lthough cohesion and coherence can [...[ be kept separate, they are not mutually exclusive since cohesive elements have a role to play in the dialogue". ${ }^{2}$

A highly important aspect of structural integrity is appropriate sentence structure, which contributes to the overall textual readability; that is, the ease with which a particular text is processed by the reader or listener (Kunilovskaya and Kutuzov 2017: 77). Under this perspective, word order should be viewed as a textual strategy rather than a feature of grammar (Baker 1992: 119). The meaning of a text is derived from the recipient's awareness of how the aforementioned lexico-grammatical markers are used to provide an intelligible information structure and from the reader's understanding of the theme and rheme (Hu 1999: 35), the two concepts that are central to the subject matter of this paper. The theme, alternatively referred to as the sentence topic, includes information which is assumed known, or which can easily be reconstructed out of broader context and to which readers can easily relate. The rheme, also known as the sentence focus, introduces new information, which is context-independent and is typically more difficult to process than the topic (for example, technical terms that are unfamiliar to the reader or phrases that contain surprising or unpredictable facts). "Because they represent new information, it is rhemes rather than themes that push text development forward" (Hatim 2003: 65). Appropriate information structure contributes to the perception of conceptual continuity and the flow of topics within the text (Menzel, Lapshinova-Koltunski and Kunz 2017: 2).

In what ways is this conceptual continuity maintained throughout the text? Lautimatti (1987) distinguishes three kinds of topical progression in a text, that is, three ways in which sentence themes cohere to ensure a logical flow of ideas (the examples are provided by the author ${ }^{3}$ ):

(1) Parallel progression - themes (topics) of successive sentences are identical or synonymous (noun phrases are repeated or replaced by anaphoric pronouns or semantic associates).

Mary is a married woman with three children. She lives in New York and works as an accountant. This ambitious woman plans to start her own business.

\footnotetext{
${ }^{2}$ This point is gaining increasing recognition in translation studies. In Hatim's (2003: 265) view, "it is becoming increasingly more common in translation studies to assume that cohesion has to be examined in terms of underlying coherence if it is to yield any useful insights. [...] Cohesion implies coherence, and it is the motivations behind the use of a particular cohesive device, rather than the device itself, that ought to be taken into consideration in the act of reworking a text".

${ }^{3}$ The sentence topics in the examples have been underscored.
} 
(2) Sequential progression - themes of successive sentences are different; that is, the rheme of a sentence becomes (or is used to form) the theme of the following sentence.

Mary is a married woman with three children. Two of them attend middle school in downtown Manhattan.

(3) Extended parallel progression - the topics of the first and last sentences in a passage (paragraph) are identical and are separated by sentences following either parallel or sequential progression. This pattern makes it possible to reinforce the main idea of the passage.

The Hart Queen is one of the best skis for beginning skiers. It has an inner core that is made up of a thin layer of ash from the hardwood forests of Kentucky. Built into its outer construction are two innovations for strength and flexibility. For increased strength, the layer of ash is reinforced with two sheets of ten-gauge steel. For increased flexibility, the sheets (they) are wrapped with fiberglass. The Queen can be used with most conventional bindings. $^{4}$

When we look at the first two kinds of progression from the perspective of translation, it seems that parallel progression seems a little easier to handle in the Polish-English language pair. Regarding sequential progression, however, given the structural differences between Polish and English, students struggle and fail to render an appropriate information structure in the target text.

\section{Students' problems with maintaining cohesion in Polish-English translation}

It is generally assumed that word order in English is relatively fixed while in Polish it is relatively free (cf., for example, Willim and Mańczak-Wohlfeld 1997: 170). Naturally, this difference stems from the fact that English is an analytical language in which relationships between words are expressed by word order, prepositions or particles whereas Polish is a synthetic language in which grammatical relationships are indicated by morphemes (for example, case suffixes in nouns). Hence, the English word order is grammatically conditioned: compared to Polish, there are far more structural restrictions pertaining to the positioning of sentence constituents. By contrast, word order in Polish is pragmatically determined: it plays a key role in assigning constituents to the thematic/rhematic part of a sentence (Górnicz 2014: 22). "Constituent order is often analyzed with respect to the structuring of information in sentences, where the constituents expressing known information strongly tend to precede the constituents expressing new information in sentences" (Willim and Mańczak-

\footnotetext{
${ }^{4}$ This extract comes from Williams (1994) and features one example of parallel progression and three examples of sequential progression between the opening and closing sentences (this time, only the topics in the first and last sentences are underscored).
} 
Wohlfeld 1997: 171). Nonetheless, it should also be mentioned here that besides pragmatic constraints the Polish word order can also be governed by formal, semantic and grammatical factors (cf., for example, Szwedek 1981). Hence, it is not as free as it is sometimes believed to be. ${ }^{5}$

The two languages share the basic SVO word order. Another common syntactic pattern in both languages features an adverbial, which can directly follow the verb or the object, or in some cases it can be used in sentence-initial position or directly after the subject (in Polish, however, there are fewer restrictions on the positioning of adverbials which can, for example, occur between verbs and objects, a pattern that is unacceptable in English: *I saw last week Peter). It should also be emphasized that Polish allows more shifts in the SVO order than English. To illustrate this point, the most common translation of the English sentence Robert liked the film would be Robertowi podobat sie film, which actually renders the OVS order in Polish (the name in sentence-initial position is in the dative). Interestingly, this Polish sentence can be re-ordered in five ways, depending on which sentence constituent is to be emphasized. Another interesting example is provided and discussed by Belczyk (2002: 65-8). The Polish sentence Aktorzy wystepuja we wtorki w pubie, which consists of a subject (aktorzy), a verb (wystepuja), an adverbial of time (we wtorki) and an adverbial of place ( $w$ pubie), can be re-arranged in as many as 11 ways, each of which reflects a different meaning focus6 (however, the differences between some of these sentences are sometimes very subtle). Its English translation, The actors perform at a/the pub on Tuesdays, can be re-ordered only in two ways: On Tuesdays, (the) actors perform at althe pub and At althe pub, (the) actors perform on Tuesdays.7 This example is a good indication of the quantitative differences in syntactic restrictions between English and Polish. Naturally, within their translator training, students typically deal with sentences that are much more demanding in terms of structure and semantics than the relatively simple examples shown above.

To identify problems related to maintaining textual cohesion in PolishEnglish translation experienced by translation trainees, the author conducted a short study halfway through the first semester of his translation class (after eight weeks of translation training). The 30 students from the Ethnolinguistics program were asked to translate ten two- or three-sentence extracts from Polish research articles (they were allowed to use online resources), all of which

\footnotetext{
${ }^{5}$ For more in-depth discussion of word order related issues, approached fromPolish-English contrastive grammar perspectives, see Fisiak, Lipińska-Grzegorek and Zabrocki (1978), Majchrzak (1978), Szwedek (1981), Duszak (1987), Willim and Mańczak-Wohlfeld (1997).

${ }^{6}$ The meaning focus is used here in the sense of preserving the theme-rheme structure.

${ }^{7}$ Naturally, English features structures that make it possible to emphasize various sentence constituents. If it was necessary to provide focus to the verb in the example in question, the sentence could be rephrased as: What (the) actors do on Tuesdays is perform (Belczyk 2002: 68).
} 
exhibited some degree of structural complexity. ${ }^{8}$ The rationale behind selecting those extracts was based on the anticipation that they might pose difficulty for the students in terms of maintaining an acceptable information structure and cohesive links across the sentence boundaries.

The study has found that as students handle longer stretches of text (sequences of sentences), they run into two general problems. First, in trying to render the information structure from the source text, they commit grammatical errors (due to syntactic interference from Polish), most commonly in word order. Second, they produce grammatically acceptable sentences, but at the same time they fail to transfer the information structure from the source text.

To illustrate these points, let us consider two examples of student translations:

Table 1. Example 1

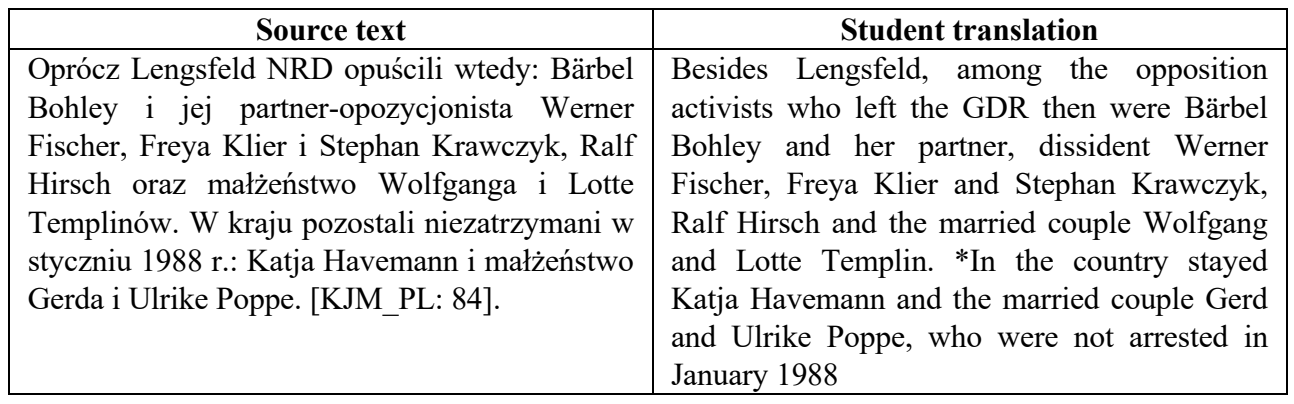

In the second sentence of the English translation, marked with an asterisk, there is an obvious error in word order, which probably results from an unsuccessful attempt to recreate the original information structure. The target sentence reflects the source sentence word order adverbial + verb + subject. With a few exceptions, which will be discussed in the subsequent section, English does not allow syntactic shifts in which the adverbial of place in sentence-initial position is followed by a verb and a subject. This word order error was made by $43 \%$ of the translation trainees (13 out of 30 ). Only one student produced an acceptable translation while the others $(50 \%)$ translated the extract using a correct word order but employing an inappropriate information structure.

Table 2. Example 2

\begin{tabular}{|c|c|}
\hline Source text & Student translation \\
\hline $\begin{array}{l}\text { We wrześniu } 1951 \mathrm{r} \text {. w Warszawie i Łodzi } \\
\text { zorganizowano pierwszą ogólnopolską } \\
\text { spartakiadę [...]. W zawodach wzięło udział }\end{array}$ & $\begin{array}{l}\text { The first Polish Spartakiad was held in } \\
\text { September } 1951 \text { in Warsaw and Łodź. 2,600 } \\
\text { athletes from the largest sports organizations in }\end{array}$ \\
\hline
\end{tabular}

\footnotetext{
${ }^{8}$ Not all of the extracts will be presented and analyzed in this paper as some of them are structurally similar to the samples discussed here.
} 
2600 sportowców z największych krajowych $\quad$ Poland took part in the event. zrzeszeń sportowych. [TS_PL: 56 $]^{9}$

This time, the translated passage is grammatically correct; however, it is difficult to process and lacking in flow. The underscored sentence subject, which is rather long, is composed of entirely new information and does not link well with the previous sentence. Sequential progression is not retained, which renders this short extract incoherent. This is how the overwhelming majority of the study participants $(93 \%)$ translated the second sentence (naturally, there were some differences in wording). The students identified the sentence subject in the source text, translated it into English, put it in sentence-initial position in the target text and added the verb and the object. The translation trainees also failed to notice that the English translation has a different meaning focus than the source sentence. They wrongly assumed that since they had found correct lexical equivalents and arranged them in an acceptable syntactic pattern, they had produced an adequate translation. It seems that in the early stages of the training process, the students are not sufficiently aware of the importance of word order in conveying meaning and ensuring cohesion. ${ }^{10}$

It is for this reason that practically from the start of their training, students should be explicitly informed about the importance of textual cohesion, which is central to maintaining conceptual continuity throughout the text. In the course of their training, they should also be acquainted with lexico-grammatical resources and procedures that can be utilized in the production of cohesive texts in the target language.

\section{Solutions to be applied in translator training}

This section will show how the transfer of conceptual relations across sentences can be achieved in the Polish-English language pair. To this aim, the following structural modifications can be applied in the target text:

1) Shifts from active to passive voice

2) Other shifts in syntactic functions

3) Fronting

4) Inventing a new sentence subject out of broader context

These operations will now be discussed one by one along with relevant linguistic examples (source text extracts and their actual published translations).

\footnotetext{
${ }^{9}$ For the purpose of the study, the source extract was slightly revised : two sentences were deleted.

10 This point can be exemplified by a few more examples of student translations from the author's class. They all share an improper information structure because the source sentence themes are rendered as the target sentence rhemes, e.g., W Poznaniu odbędzie się kolejny Festiwal Rzeźby Lodowej (Another Ice Festival will take place in Poznan), Pierwsza nagrodę otrzymat francuski pianista (A French pianist received first prize), and $W$ Londynie mieszka okoto milion obywateli UE (About a million EU citizens live in London).
} 
To provide a better understanding of conceptual relations across sentences, words and phrases serving as cohesive links will be underscored while the rhemes of the transformed target sentences will be boldfaced.

\subsection{Shifts from active to passive}

We will look again at the source extract from example 2 and its actual translation.

Table 3

\begin{tabular}{|c|c|}
\hline Source text & Target text \\
\hline $\begin{array}{l}\text { We wrześniu } 1951 \text { r. w Warszawie i Lodzi } \\
\text { zorganizowano pierwszą ogólnopolską } \\
\text { spartakiade }[\ldots] . \text { W zawodach wzięlo udzial } \\
\mathbf{2 6 0 0} \text { sportowców z największych krajowych } \\
\text { zrzeszeń sportowych. [TS PL: 56] }\end{array}$ & $\begin{array}{l}\text { In September 1951, the first National } \\
\text { Spartakiad was held in Warsaw and Łódź } \\
\text { [...].The event was attended by } \mathbf{2 , 6 0 0} \text { athletes } \\
\text { from Poland's largest sports organisations } \\
\text { [TS ENG: 298]. }\end{array}$ \\
\hline
\end{tabular}

The second sentence in this short passage is an example of sequential progression: part of the rhematic section of the first sentence becomes the theme of the following one (pierwsza ogólnopolska spartakiade $\rightarrow w$ zawodach). This cohesive link is also present in the English translation (the First National Spartakiad $\rightarrow$ the event), which differs considerably from the student translation in example 2. The first difference is that the sentence has a new and short subject (the event). Then a passive verb is used, which makes it possible to shift new information, contained in the long and complex noun phrase, where it pragmatically belongs, i.e. towards the sentence ending.

Passive voice is employed less frequently in Polish than in English ${ }^{11}$, which may partially explain why it was not used in the student translation (example 2 in the previous section). ${ }^{12}$ It cannot be denied that passive structures have several advantages and, in some contexts, they serve as better choices than the active. Passive voice is preferred whenever the agent is unknown or is unimportant to the reader. It can also be used when the writer intentionally wants to hide the agent (for example, to avoid assigning responsibility). Moreover, the passive frequently contributes to a better information flow, enhancing textual cohesion (it helps to locate the reader in a context of what they already know). Finally, it helps to focus the reader's attention on a limited number of semantically linked concepts, providing thus a consistent point of view. In purely grammatical terms,

\footnotetext{
${ }^{11}$ This is largely due to several structural restrictions in Polish. For example, the indirect object of the active verb cannot be made the subject of the passive sentence. For more insights, see Willim and Mańczak-Wohlfeld (1997: 160-2).

${ }^{12}$ Besides attend, there are several common English verbs that do not have passive equivalents in Polish.
} 
thanks to passive structures it is sometimes possible to avoid unnecessary subject changes within a passage (Williams 1994: 72-6).

\subsection{Other shifts in syntactic functions}

Like in the previous category, these shifts entail the choice of a new sentence subject. However, as this kind of transformations causes even more difficulty for students, it will be illustrated with two examples.

Table 4

\begin{tabular}{|c|c|}
\hline Source text & Target text \\
\hline Pierwsze masowe migracje ludności w obu & The first wave of $\mathrm{m}$ \\
\hline kierunkach odnotowano zaraz & of Russia occurred right after the collapse of \\
\hline Związku Radzieckiego. [...] W okresie od 1989 & the Soviet Union. [...] From 1989 to 2004 , the \\
\hline do 2004 r. do Federacji Rosyjskiej przyjechało & Russian Federation received from 4.9 to 8.2 \\
\hline $\begin{array}{l}\text { od } 4,9 \text { do } 8,2 \text { mln mieszkańców } z \text { państw } \\
\text { WNP i republik nadbaltyckich. [AS_PL: 124- } \\
5]\end{array}$ & $\begin{array}{l}\text { million people from other CIS states and the } \\
\text { Baltic republics. [AS_ENG: } 274 \text { ] }\end{array}$ \\
\hline
\end{tabular}

Polish texts frequently feature adverbials of time and place in sentence-initial position. In the second sentence of the source text there is an adverbial of time ( w okresie od 1989 do 2004 $\rightarrow$ from 1989 to 2004) followed by an adverbial of place (do Federacji Rosyjskiej $\rightarrow$ to the Russian Federation). In English, such sequences of adverbials are not very common, and in the above example, they would be grammatically unacceptable in sentence-initial position. To avoid this kind of mistake, most of the study participants $(63 \%)$ offered a translation with significant changes to word order as compared to the source text. Here is an example: From 1989 to 2004, from 4.9 to 8.2. million people from other CIS states and the Baltic republics arrived in the Russian Federation. While this sentence is grammatically correct, it is stylistically awkward (primarily due to the lengthy subject) and does not link well with the preceding sentence. To provide an appropriate connection, it is necessary to invent a different subject, which in this particular case is the noun phrase the Russian Federation. However, this change in a syntactic function means that a translator needs to use a verb that would collocate with the subject and object (here receive). Needless to say, such alternations prove to be a daunting task for translation students.

Let us consider one more example. 
Table 5

\begin{tabular}{|c|c|}
\hline Source text & Target text \\
\hline $\begin{array}{l}\text { Celem „,ideowym” } \text { PUWFiPW }^{13} \text { miało być } \\
\text { „rozwijanie i utrzymanie tężyzny fizycznej } \\
\text { obywateli Rzeczypospolitej dla zapewnienia } \\
\text { siłom zbrojnym Rzeczypospolitej Polskiej } \\
\text { Żołnierza - Obywatela, obrońcy jej granic i } \\
\text { ustroju demokratycznego”. Kierownikiem } \\
\text { nowego urzẹdu został bezpartyjny, } \\
\text { przedwojenny lwowski działacz sportowy } \\
\text { Tadeusz Kuchar [...]. PUWFiPW oraz } \\
\text { PRWFiPW podlegał także utworzony w marcu } \\
\text { 1946 r. Związek Polskich Związków } \\
\text { Sportowych (ZPZS) z prezesem Alfredem } \\
\text { Lothem. [TS PL: } 35-6]\end{array}$ & $\begin{array}{l}\text { The PUWFiPW's "ideological" objective was } \\
\text { "to develop and maintain the physical fitness } \\
\text { of Polish citizens with a view to educating and } \\
\text { training Citizen Soldiers for the Polish armed } \\
\text { forces, who would defend Poland's borders } \\
\text { and its democratic system". The institution } \\
\text { came to be headed by Tadeusz Kuchar, a } \\
\text { nonpartisan pre-war sports official in Lviv } \\
\text { (now Ukraine) [...]. The PUWFiPW and the } \\
\text { PRFWiPW also oversaw the work of the } \\
\text { Association of the Polish Sports Associations } \\
\text { (ZPZS), established in March 1946, and } \\
\text { headed by Alfred Loth. [TS ENG: 283] }\end{array}$ \\
\hline
\end{tabular}

The Polish extract is an example of parallel progression with identical or similar sentence themes (this time, the rhemes are not boldfaced). What posed a challenge for the translation trainees is the OVS word order in the second and third sentences of the source text with the themes in the instrumental and dative cases, respectively. A simple switch to the SVO order without any other modifications in the translation process would yield sentences with an improper information structure, rendering the entire passage incohesive. ${ }^{14}$ To avoid stylistic awkwardness, it is necessary to put the sentence themes in subject position, and invent appropriate new verbs that combine with the subjects and the remaining constituents of the two sentences. As a result, new information contained in the elaborate noun phrases (which are fairly difficult to process), is placed in the latter parts of the sentences, after the subject and the verb. This shift secures cohesion and eases proper interpretation of the passage.

\subsection{Fronting}

\footnotetext{
${ }^{13}$ The source text is an extract from a research paper on the role of Polish sport in the propaganda machine during the Stalinist period. The two acronyms used in the extract, the PUWFiPW and the PRWFiPW, stand for the names of two communist institutions: Państwowy Urząd Wychowania Fizycznego i Przysposobienia Wojskowego (The State Office of Physical Education and Military Training) and Państwowa Rada Wychowania Fizycznego i Przysposobienia Wojskowego (The State Council of Physical Education and Military Training). The study participants were provided with this information to ease their translation work.

${ }^{14}$ As many as $97 \%$ of the students had issues with this passage. Here is a sample translation that reflects an inappropriate information structure: Tadeusz Kuchar, a nonpartisan pre-war sports official in Lviv (now Ukraine) became head of the new institution. The Association of the Polish Sports Associations, established in March 1946, and headed by Alfred Loth, came under the PUWFiPW and the PRWFiPW. As can be seen, the extremely long sentence subjects are entirely composed of new information.
} 
This procedure involves less typical, non-SVO word orders in English and "refers to the initial placement of core elements which are normally found in post-verbal position" (Biber 1999: 900). Fronting will also be illustrated with two examples.

Table 6

\begin{tabular}{|c|c|}
\hline Source text & Target text \\
\hline $\begin{array}{l}\text { Droga obok domu naszych dziadków } \\
\text { prowadziła na niezbyt odległy kirkut i co jakiś } \\
\text { czas przechodzil ta droga czarny orszak } \\
\text { pogrzebowy z zawodzącymi placzkami. } \\
\text { [PS PL: } 243]\end{array}$ & $\begin{array}{l}\text { The road along our grandparents' house led to a } \\
\text { nearby Jewish cemetery. Now and then, down } \\
\text { that road came a black funeral procession } \\
\text { with weeping female mourners. [PS_ENG: } \\
\text { 328] }\end{array}$ \\
\hline
\end{tabular}

In the target text, a common word order SVA is reversed so that the adverbial of place precedes the verb and the subject. This shift provides a semantic link with the previous sentence (note that in the translation process, the source sentence has been rendered as two sentences in the target text). As a result of this transformation, new information is placed where it pragmatically belongs, and constitutes the rhematic part of the sentence. Subject-verb inversion involves adverbials of time and place and is restricted to a relatively small set of verbs of location and movement, such as: be, stand, lie, go, come, fly, sail and a few others.

Table 7

\begin{tabular}{|c|c|}
\hline Source text & Target text \\
\hline $\begin{array}{l}\text { Operatorzy kamery starali się przede } \\
\text { wszystkim ukryć skandaliczne warunki w } \\
\text { jakich odbywało się spotkanie, mimo } \\
\text { sugestywnego głosu lektora: „Pokryte błotem } \\
\text { boisko nadawałoby się raczej do kąpieli } \\
\text { borowinowej”. O wiele ważniejsze dla } \\
\text { realizatorów dokumentu były wypelnione po } \\
\text { brzegi trybuny [TS PL: 50] }\end{array}$ & $\begin{array}{l}\text { The cameramen went to great lengths not to } \\
\text { show the scandalous conditions on the pitch. It } \\
\text { was only thanks to the newsreader that we } \\
\text { learned that "the mud-covered pitch was more } \\
\text { suitable for a peat bath". Far more important for } \\
\text { the documentarians was the fully packed } \\
\text { stadium. [TS_ENG: 292] }\end{array}$ \\
\hline
\end{tabular}

In English, for emphatic purposes, it is also possible to put comparative and superlative phrases at the beginning of a sentence. As previously, in the above example, fronting allows starting the second sentence in the target text with known information, thus establishing a cohesive link with the preceding sentence. This kind of transformation can only be performed with the copula verb be. Adjective fronting proved relatively easy to handle by the study participants (a total of $70 \%$ of the students employed this procedure in translation), probably due to syntactic similarities between English and Polish. Interestingly, the same was not true of adverbial fronting despite another structural similarity (students either applied the SVA order or inserted the 
existential there before the verb). Only $23 \%$ of the students proposed a translation with an adverbial of place followed by a verb and a subject.

\subsection{Inventing a new sentence subject out of broader context}

To exemplify the last procedure, we will go back to example 2 from section 2.

Table 8

\begin{tabular}{|c|c|}
\hline Source text & Target text \\
\hline $\begin{array}{l}\text { Oprócz Lengsfeld NRD opuścili wtedy: Bärbel } \\
\text { Bohley i jej partner - opozycjonista Werner } \\
\text { Fischer, Freya Klier i Stephan Krawczyk, Ralf } \\
\text { Hirsch oraz małżeństwo Wolfganga i Lotte } \\
\text { Templinów. W kraju pozostali niezatrzymani } \\
\text { w styczniu 1988 r.: Katja Havemann i } \\
\text { małżeństwo Gerda i Ulrike Poppe. [KJM_PL: } \\
\text { 84] }\end{array}$ & $\begin{array}{l}\text { Besides Lengsfeld, among the opposition } \\
\text { activists who left East Germany then were } \\
\text { Bärbel Bohley and her partner, dissident } \\
\text { Werner Fischer, Freya Klier and Stephan } \\
\text { Krawczyk, Ralf Hirsch and the married couple } \\
\text { Wolfgang and Lotte Templin. The dissidents } \\
\text { who stayed in the GDR included Katja } \\
\text { Havemann and the married couple Gerd } \\
\text { and Ulrike Poppe, who were not arrested in } \\
\text { January 1988. [KJM ENG: } 228 \text { ] }\end{array}$ \\
\hline
\end{tabular}

As implied above, such source text extracts as the one above are very difficult to render in English (only one out of the 30 study participants produced a structurally acceptable translation). The second sentence as well as the first one is composed almost solely of new information. It is not feasible to apply any of the previous solutions. For example, none of the words or phrases from the source extract can be turned into a new sentence subject in the target text. Potential "candidates" for a subject in the second sentence could be the proper name East Germany or the noun phrase the country, but they do not combine with any verbs to form a grammatical sentence. Hence, when all else fails, a possible solution is to reconstruct the topic out of broader context (in other words, we need to rely on conceptual and pragmatic connectivity). Since the entire paper is about female dissidents in the former East Germany, the sentence themes should include a reference to the main topic. Therefore, the first sentence contains the phrase the opposition leaders while the second one - the dissidents, which along with the clause who stayed in the GDR forms the subject (in the first sentence, we have subject-verb inversion, and the phrase opposition leaders is part of the adverbial placed in sentence-initial position). The inserted phrases thus serve as semantic links ensuring textual cohesion.

Interestingly, the above solution is an exemplification of what Blum-Kulka (1986: 18) calls a shift in the level of explicitness. As she argues, adding new words in the translation process results in the greater redundancy of the target text. As a procedure, explicitation is viewed as a translation universal: target texts exhibit greater explicit cohesion compared to their originals (cf., e.g., Chesterman 2004: 8). 


\section{Conclusion}

The last example is probably the best exemplification of a point made in the introductory section that there is an interplay between cohesion and coherence. Conceptual relations within the text (coherence) have proved central to finding appropriate linguistic manifestations (cohesion) that reinforce these relations.

It has also been shown that a proper information structure, which is realized through the thematic/rhematic progression, can contribute to textual intelligibility, readability and explicitness. In this respect, of paramount importance is the ability to use appropriate target language structures because "atypical features of translations [...] have a greater negative impact on the overall textual quality than lexical translationese. Inadequate syntactic structures bring about various issues with target text fluency, which reduces readability and the reader's chances to get to the text message" (Kunilovskaya and Kutuzov 2017: 75).

In translator training, cohesion should be viewed as an essential aspect of textual competence (Schäffner 2000: 146). A natural question that arises is: how can translation students be taught to maintain cohesive links in longer stretches of target texts? The first step could entail a careful analysis of source language extracts with the objective of focusing trainees' attention on the thematic/rhematic progression: students could be asked to identify sentence themes and rhemes. Then they should be exposed to sample translations (performed by professionals) of the Polish extracts to see the procedures that have been applied to secure cohesion across sentence boundaries. Finally, students could be requested to translate short passages from Polish into English, having been previously instructed to pay special attention to maintaining cohesion.

The present contribution is prescriptive in nature as it is primarily designed to serve teaching purposes. However, it is also meant to prompt further research in this area. The aforementioned aspects of cohesion in the translation process certainly deserve to be addressed in more extensive descriptive and quantitative studies that would be based on parallel corpora of Polish texts and their English translations.

\section{References}

Baker, Mona. 1992. In other words (A coursebook on translation). London/New York, Routledge. https://doi.org/10.4324/9780203133590

Belczyk, Arkadiusz. 2002. Poradnik tlumacza: z angielskiego na nasze. Kraków: Idea.

Biber, Douglas, Johansson Stig, Leech Geoffrey, Conrad Susan and Finegan Eward. 1999. The Longman Grammar of Spoken and Written English. London, Longman.

Blum-Kulka, Shoshana 1986. Shifts of cohesion and coherence in translation. In J. House and S. Blum-Kulka (eds.), Interlingual and Intercultural Communication: Discourseand Cognition in Translation and Second Language Acquisition Studies, 17-36. Tübingen: Gunter Narr. 
Chesterman, Andrew. 2004. Hypotheses about translation universals. In G. Hansen, K. Malmkjær and D. Gile (eds.), Claims, Changes and Challenges in Translation Studies: Selected contributions from the EST Congress, Copenhagen 2001, 1-13. Amsterdam/Philadelphia: John Benjamins Publishing Company. https://doi.org/10.1075/btl.50.02che

Duszak, Anna. 1987. The dynamics of topics in English and Polish. Warszawa: Wydawnictwa Uniwersytetu Warszawskiego.

Fisiak, Jacek, Lipińska-Grzegorek Maria, and Zabrocki Tadeusz. 1978. An introductory EnglishPolish contrastive grammar. Warszawa: Państwowe Wydawnictwo Naukowe.

Górnicz, Mariusz. (2014) Hipertematy a szyk zdania w polskich tekstach specjalistycznych. In M. Kornacka (ed.), Spójność tekstu specjalistycznego, 21-29. Warszawa: Wydawnictwo Naukowe Instytutu Kulturologii i Lingwistyki Antropocentrycznej Uniwersytet Warszawski.

Halliday, Michael A. K. 1985. An introduction to functional grammar, London: Edward Amold.

Halliday, Michael A. K. and Hasan Ruqaiya. 1976. Cohesion in English. London: Longman.

Hatim, Basil. 2003. Text linguistics and translation. In M. Baker (ed.), Routledge Encyclopedia of Translation Studies, 262-265. New York: Routledge.

$\mathrm{Hu}$, Helen Chau. 1999. Cohesion and coherence in translation theory and pedagogy, Word, 50(1), 33-46. https://doi.org/10.1080/00437956.1999.11432482

Kaczmarek, Karolina. 2014. Interpretacja terminologii związanej $\mathrm{z}$ teorią tekstu $\mathrm{w}$ aspekcie spójności (aspekt synchroniczny i diachroniczny w kształtowaniu się znaczeń na przykładzie terminów kohezja i koherencja)". In M. Kornacka (ed.), Spójność tekstu specjalistycznego, 3039. Warszawa: Wydawnictwo Naukowe Instytutu Kulturologii i Lingwistyki Antropocentrycznej Uniwersytet Warszawski.

Kerremans, Koen. 2017. Applying computer-assistedcoreferential analysis to a study ofterminological variation in multilingualparallel corpora. In K. Menzel, E. LapshinovaKoltunski, and K. Kerstin (eds.), New perspectives on cohesion and coherence: Implications for translation, 49-74. Berlin: Language Science Press.

Kunilovskaya, Maria and Kutuzov Andrey. 2017. Testing target text fluency: A machine learning approach to detecting syntactic translationese in English-Russian translation. In K. Menzel, E. Lapshinova-Koltunski and K. Kerstin (eds.), New perspectives on cohesion and coherence: Implications for translation,75-103. Berlin: Language Science Press. https://doi.org/10.1515/9783110459586-010

Lautimatti, Liisa. 1987. Observations on the development of the topic of simplified discourse. In U. Connor and R. B. Kaplan (eds.), Writing across languages: Analysis of L2 text, 87-114. Reading: Addison-Wesley.

Majchrzak, Konrad. 1978. The structure of the noun phrase in English and Polish: a contrastive analysis (unpublished $\mathrm{PhD}$ dissertation), Poznań.

Menzel, Katrin, Lapshinova-Koltunski Ekaterina and Kerstin Kunz. 2017. Cohesion and coherence in multilingual contexts. In K. Menzel, E. Lapshinova-Koltunski and K. Kerstin (eds.), New perspectives on cohesion and coherence: Implications for translation, 1-10. Berlin: Language Science Press.

Schäffner, Christina. 2000. Running before walking? Designing a translation program at undergraduate level. In C. Schäffner and B. Adab (eds.), Developing translation competence, 143-157. Amsterdam: John Benjamins Publishing Company. https://doi.org/10.1075/btl.38.14sch

Szwedek, Aleksander. 1981. Word order, sentence stress and reference in English and Polish. Bydgoszcz: Wydawnictwo Uczelniane WSP.

Tanskanen, Sanna-Kaisa. 2006. Collaborating Towards Coherence: Lexical Cohesionin English Discourse. Amsterdam/Philadelphia: John Benjamins Publishing Company. https://doi.org/10.1075/pbns.146

Williams, Joseph M. 1994. Style: Ten Lessons in Clarity and Grace. New York: HarperCollins. 
Willim, Ewa and Mańczak-Wohlfeld Elźbieta. 1997. A contrastive approach to problems with English. Warszawa/Kraków: Państwowe Wydawnictwo Naukowe.

\section{Abbreviations and extract sources:}

AS_PL: Szabaciuk Andrzej 2016. Polityka ludnościowa jako element strategii odbudowy pozycji imperialnej Federacji Rosyjskiej, Przeglad Zachodni, issue 4: 117-133.

AS_ENG: Szabaciuk, Andrzej 2017. Population Policy as a Significant Element of a Strategy for Rebuilding the Imperial Position of the Russian Federation, Przeglad Zachodni II, 267-283.

KJM_PL: Jedynakiewicz-Mróz, Katarzyna 2017. Rozważania na temat działalności kobiet w opozycji demokratycznej w późnej NRD (1981-1989), Przegląd Zachodni, 1, 75-95.

KJM_ENG: Jedynakiewicz-Mróz, Katarzyna 2018. Reflections on the Involvement of Women in the Democratic Opposition in the Late East Germany (1981-1989), Przeglad Zachodni, 219239.

PS_PL: $\quad$ Skubiszewski, Piotr 2015. O moim bracie, Przeglad Zachodni: issue 3: 237-254.

PS_ENG: Skubiszewski, Piotr 2017. About my brother, Przeglad Zachodni I: 321-340.

TS_PL: Sikorski, Tomasz 2018. Propagandowy obraz polskiego sportu w Polskiej Kronice Filmowej w okresie stalinizmu (1949-1956), Przeglad Zachodni, 4, 35-60.

TS_ENG: Sikorski, Tomasz 2019. A propagandised image of Polish sport in the Polish Film Chronicle during the Stalinist Period (1949-1956), Przeglad Zachodni, 283-302. 